\title{
Human ecosystems in critical areas
}

\author{
Oleg N. Yanitsky \\ Institute of sociology Russian academy of sciences
}

\begin{abstract}
The author attempts to evaluate the recent terrorists' attacks in the light of his concept of critical areas. The theoretical differences between the concepts of the critical areas and of a state of emergency are explicated with a focus on processes of socio-ecological metabolism. Using the ecosystem method he considers the response of various levels of a human community, from global to local, i.e. from international to individual: global, national, group and individual. The article is ended with the following preliminary conclusions. First, the critical areas are usually spatially fixed whereas a state of emergency is indifferent in its scale and consequences. Second, the major features of terrorists', type of human ecosystems are the following: unseen, maximum closed, network-structured, armed and aimed at the distraction of the existing social order. Third, any state of emergency is a kind of all-embracing risk in its utmost form. It cannot be conquered by one mighty strike of a state power. The struggle against terrorism is a multisided and long-term process. Four, Schools, universities, sciences and media should not only to inform people but teach them how to behave in critical cases. Five, the terrorism can be represented and studied as a specific human ecosystem. Six, any critical system seriously changes an existed man-nature social metabolism. Seven, a study of an extreme way of life is as important as normal one. Eight, in the global risk society all social institutes should be prepared to respond to the emerging risks locally, i.e. here and now. Terrorism as a social phenomenon is a high-level risk but urges state and civil society to work hand in hand. Ten, the kind of socio-ecological metabolism is an indicator of stability of any social order.
\end{abstract}

\section{Indexing terms/Keywords}

all-penetrating risk, civil society, critical area, human ecosystem, social institutions, socio-ecological metabolism, state of emergency, terrorism

\section{Academic Discipline And Sub-Disciplines}

Sociology

\section{SUBJECT CLASSIFICATION}

Library of Congress Classification: Subclass HM - Sociology (General)

\section{TYPE (METHOD/APPROACH)}

theorizing, review of professional literature, media analysis, personal experience

\section{Council for Innovative Research}

\section{Peer Review Research Publishing System}

\section{Journal: Journal of Social Sciences Research}

\author{
Vol. 9, No. 3 \\ editor@jssronline.com
}

www.jssronline.com 


\section{Theoretical differences between the critical area and the state of emergency concepts}

Earlier, I defined the critical area as a territory (zone) in which the production of 'goods', using the Beck's terminology, permanently lags behind the production of 'bads' (Beck, 1992, 1999, 2015; Yanitsky, 2014). As recent events in Paris, Brussels and other European cities shows the state of emergency should be considered as a process, at least in terms of politics and sociology. One of the distinguishing features of the state of emergency is sharply changed socio-ecological metabolism. In western literature, there is a tradition to analyze an urban metabolism mainly in terms of resource flows (Newcomb et al., 1978; Boyden et al., 1981; Kennedy et al., 2007; Fisher-Kowalski, 1997; Fisher-Kowalski and Haberl, 2007). It is important but not sufficient for the case under consideration. Let's step back for at least half-a-year and have a look at situation in the EU. What is clear now? First, it was a mighty flow of migrants of entirely another culture and habit of life, without knowledge of any European languages. It is quite natural that they cannot adapt to European culture at once. As it became clear later, many of them didn't want to adapt. Second, the railroads have been overcrowded, and its stations turned into temporary refugees' camps. In sum the transport infrastructure has been disorganized for a while. Third, the refugees' crowds and camps suddenly emerged here and there. Police and army troops have been mobilized. Tension and clashes have permanently emerged between them. Four, there were no programs including IT-models for regulation this flow, informing newcomers as well as for overall the EU control and governing this influx. It turned out that there was no doctrine of how to foresee and overcome such risks. Some urgent measures related to quoting are still suspended. Five, therefore politically and technologically advanced Europe turned out unprepared to this issue. The European political class literally stuck in endless talks about quotas of refugees to be accepted and adapted by particular member-states. It is indicative that some of them initially refused to accept refugees from particular countries. It is surprisingly that there was neither global forecasting system nor how to resist to such global risks. It seems that nobody at the EU top level has been prepared to unpredictable and unintended shifts of the global social order about which many eminent political scientists and sociologists warned many times ago. It is more surprisingly because Europeans do participate in disorganization of social order in the Northern Africa. Six and it is the most important. It turned out that the EU social order has been seriously challenged. The tension between the member-states is growing. And I suppose that this weakness is not for months but for years. Of course, it is not going on the decay of the Union but it rather bulky and awkward political structure is not fit to sudden challenges both inside and outside. In particular, the needs and accusations from some refugee groups have not been taken into account. Up to now, European politics fully seems not realized that if the EU needs in new 'labor power' from abroad it consist of individuals who have their own interest. Finally, this influx must be considered not as a difficult but resolvable issue but as a 'clash of civilizations.'

A state of emergency in sociological terms is something different. The struggle with the ISIL and a set of terrorist attacks in France and Belgium sharply aggravates the situation. A state of emergency and its local variants is the upper (i.e. the most serious) stage of a critical situation and simultaneously of all-embracing risk. The matter is that critical events terrorists' attacks, explosions and even use of chemical and biological arms - may happen in any part of the EU. This is another manifestation of the all-embracing and all-penetration risk phenomenon. As one could see, the retaliatory measures are necessary but they are traditional in character. If the terrorists' strike have been sudden, multisided and network-the response must be adequate. But it is a general principle which is not excludes all usual measures: mobilization of defense, rescue and charity forces and dispersal of any crowed places. This is important but not enough. Armed forces could not defend any particular individual. Thus, the problem of civic defense is emerged. In this some forms of social networks could be useful. It is again is double-sided instrument because it could be used by terrorists. Nobody can assure you that your secret code could not be decoded by IT-specialist collaborating with radicals. Therefore, 1 consider the struggle with terrorists in situ as races with a Devil. As one American Special Operation Intelligence veteran said, this virulent (i.e. terrorist) ideology powers Islamic state. This state is not a sect of Islam, but a death cult powered by an apocalyptic vision. To beat them, the West must fight against that vision. Ideas are harder to fight than a military force. If this strategy will be accepted we must to shift our efforts simultaneously within and abroad to the cells and networks in which this ideology cultivated and disseminated. Then, if terrorists act overtly a network of special services must be developed. When media announced that a terrorist was captured or killed it has positive psychological effect but it is actions 'in pursuit' but not an outstripping one. Of course, there is a risk to slide down into overall suspiciousness and denunciation. Anyhow, the race of 'goods' and 'bads' is endless. But the ideological struggle against terrorism is as important as preventive police and military actions. The preliminary outcome is that the world entered into a new form of warfare.

\section{The state's response}

Preliminary remarks: this section is written from the viewpoint of socio-ecological metabolism. Western researchers focused their research in this field on resource metabolism of cities (Ermolaeva, 2015; Yanitsky, 2013). In her literature review Ermolaeva came to the conclusions that: (1) historical and anthropological approaches are dominating; (2) attempts to expand an interdisciplinary research practice; (3) an accent on the study of material and resource flows which, as there researchers think, demonstrate an importance of these flows foe urban management; and (4) the use of mathematical modeling (Ermolaeva, 2015: 45). That is why I tried to expand the notion of metabolism, that is, to analyze interrelationships between different parts of a society and other human ecosystems at risk (Yanitsky, 2014).

The immediate response in France and Belgium was well understandable: to minimize risk of the terrorist's attack and to calm the people as much as possible. The following measures had been taken: to minimize any concentration of citizens, to offer necessary medicine aid to injured and shocked, and to defense major offices and vital infrastructures. There were at least four levels of defense actions: the EU, national, regional, municipal and local. The following texts are the 
quotations from Reuters.com. 'Brussels put on maximum alert on risk of Paris-like attack.' 'The city's museums and many cinemas and sport centers were shut. Clubs and venues cancelled events. For the reason of maximum security alert the metro stations have been shut, and authorities asks the residents and tourists to avoid any crowding anywhere (in shopping centers, concerts, sport events and even at public transport hubs. Local authorities were called to postpone soccer matches as well as visits of the EU officials and individual and tourist groups. Besides, the federal prosecutors said that weapons had been found at the homes of terrorists. Interior minister of Belgium said that we needed to register everyone who lives in Molenbeek (the Arabian neighborhood of Brussels) because of it was not clear at present who was at each address... It means that potential terrorists had never been registered before and above weapons and explosives had been transported and accumulated in cities for a long time. The government's crisis center has been organized, etc.

What all these means from the human ecosystem viewpoint? First of all, that habitual life at all levels of the EU social organism had been seriously shacked. One should keep in mind that the EU is densely populated area with oversaturated infrastructure including social, electro, gas-and-oil networks. The technical and social infrastructures are tightly knitted. Above all, these infrastructures have rather complicated systems of regulation and 'tuning.' If one is urgently needed to be restricted or even blocked, it could exert a multisided negative impact on the other. For example, the northern part of Europe is built on polders and full of channels and other water devices. Besides, France and some other countries are full of nuclear power plants. So if any accident would happen, especially in the northern part of the EU, it could exert harm upon thousand inhabitants and to threaten other thousands. Then, special mobility of the EU population is growing year by year. To check every car and every railroad passenger is impossible. It means that this densely populated and mobile area is risky as such, without any outward source of harm. Visiting the UK in 1974 for the first time, l'd been actually astonished seeing how ordinary inhabitants looked after their flowers stand on the knees because their plots had been so small and close one another. After then, the invention of various forms of internet communications has made this human ecosystem much dense. The reverse side of the coin is an inversion of the space engendered by IT-communications and growing speed of other means of transportation. As a result, if something happens in one part of human ecosystem it is immediately echoes it its other part. And what is important this network can be used by any asocial and criminal actors. The contradictory trends have emerged: the state wants to make society much more transparent whereas civil society being at risk nevertheless attempts to protect its privacy because of it is one of fundamental values of western world. By privacy in crowded places is possible when individual/family/small group are assured that they are in a safe milieu. In turn, safe crowded milieu presupposes mutual trust with those who are around. Critical accidents alienate people making them suspicious. Anyhow, there will be no mass marches as in January after the Sharlie Hebdo has been attacked.

The problem of principles and structure of potential terrorists' ecosystem is of a no less importance. At the first glance, this structure is simply built in the networks of the modern world. Yes, because of the radicals use the same cellphones and other devices, the same means of transportation as others, etc. There are two hypotheses which must be empirically tested. The first one explains the critical accidents by the weakness of police and other special forces and by too much trust of ordinary citizens. The second presupposes that terrorists already have the well-structured and secret their own network. But there is a problem of a more general character. As D. Smith pointed out, a sociologist should bring into that situation 'a broader understanding of the dynamics of humiliation, and overall picture of the ways in which individuals, groups or whole societies might deal with their anger and resentment.' But how we should deal with this practically? Smith continued, 'If a sociologist engaged in participant observation experiences humiliation as a result of sharing the life and social location of a particular group, this fact may allow the researcher to take away from the situation new insight into the group's code of values, sense of justice and world view. It may also show the researcher that specific situations and events he or she may not have thought about have the potential to inflict humiliation' (Smith, 2008: 376 , his italics). In any critical situations it is rather dangerous for the researcher to play a role of participant, i.e. included, observer. Both Russian and western sociologists are inclined to do with open, i.e. democratic methods of data gathering. Mass opinion surveys in which a researcher is rather distant from his respondents prevails across the world. I realize that this is a rather comfortable and safe position. Journalists who are working in the 'hot spots' supplied sociologists with important but still insufficient information, because of the journalists fix what is happening 'here and now.' An ordinary sociologist never gives his or her consent to work as a secret agent. Does it mean that we doom to work only with the results of secondary analysis? To gain facts from those few who attends official briefings? It is another important source of information but it is going again on the information form 'above.' In my view, the sociologists could gain rather substantial information from the hands of historians and anthropologists who are well acquainted with long-term trends. Anyhow, we must not lose heart and should move toward more cloze interdisciplinary contacts combining top-down and bottom-up views.

Let us shift the focus of our interest toward an international level. the EU, the US, China, Russia and many other countries and their conglomerates have adopted many international and bi-lateral agreements related to critical zones around the world (as to Afghanistan, Kenya, Syria, Ukraine and to many others) have been adopted but not fully implemented until now. On the one hand, this situation is explained by difficulties of practical implementation. But on the other hand, a 'symbolic behavior' of majority of European politics is a distinguishing feature of their mode of decision-making concerning critical zones. Only critical events like terrorists' attack in Paris urged top politicians to adopt more decisive measures. One of the major impediments here is an excessive bureaucratization of modern decision-making and clashes of interests of main stakeholders in situ. The bureaucracy is not only a social strata, it is well structured ecosystem with principles and rules quite different from the legal structure of the world and national institutions. This is the major impediment for exact and timely implementation of adopted decisions. Besides, the result of functioning of these overt ecosystems is growing lag behind of necessary measures from the processes of rapidly changing human ecosystems. All this speaks for the necessity of timely and careful qualitative analysis of changes in socio-ecological metabolic processes. The general rule is: every action of any social subject must be carefully prepared to minimize undesirable effect in all other parts of a 
human ecosystem. This means that we are needed in a more developed future research and forecasting based on interdisciplinary approach.

As to changes in social order, there are at least three models of it which should be mentioned. The first is based on the principle of a social compact. This kind of public agreement restricts an individual or group interest by historically and culturally developed social norms. In essence, such public contract is a mutually adopted system of legal and social institutions. Ideally, the metabolic processes should correspond to this secular type of society (the violations of these processes by egoistic interests pursued by a particular actor are not considered here). The second type of social order is based on a contradictory mix of the weakening public contract and the strengthening kinship and interpersonal ties. The latter system is actually parasitizes on the former one. Today, these two types of social order have knitted well. The third type of social order has emerged when public contract is practically replaced by prevailing ideological dogmata. The state is losing its secular character. Often this type of social order is converted into a set of local communities which are permanently struggle each other for power and influence. Accordingly, the type of socio-ecological metabolism gradually changed. At the beginning, it gradually become weaker, the control on metabolic processes in situ and around is weakening as well. Then, the second form of social order represents a combination (or a conglomerate) of modern and traditional values, social norms and ways of life. A public concern with regional and global metabolic processes drops. The third form of social order is featured by the prevailing of traditional and even archaic norms and ways of life and correspondingly by locally oriented socio-ecological metabolism. A community interest to metabolic processes of a larger scale is practically lost except cases of interference from the outside. But globalization is destroying these closed and locally-depended communities. But these are 'normal', i.e. typological models (archetypes). But how to correlate the basic human right for privacy and the 'privacy' of those who aimed at to undermine this right and threatened to every individual health and life?

A geopolitical aspect of the relationships between types of social order and kind of socio-ecological metabolism needs a detailed analysis. Here I would make three remarks only. First, in the run of about 45 years (the first global ecological summit in Stockholm was in 1972) the United Nations cannot develop world agenda on long-term practical measures for protecting of the Earth environment. In the poorest countries the nature ecosystems and their gifts are still the only one resource for survival of local people. Second, in the run of this time span the global environmental metabolism has seriously changed under brutal pressure of changing man-made environment. In particular it is a result of current redistribution of flows of goods, people, energy, etc. as well as of permanently changing disposition of world, regional and local powers. Third, during this period the basic principle of man-nature relationships has not changed seriously. Every year the mankind is expanding his interference into natural ecosystems and enlarging the flow of wastes and other byproducts into them. As recent environmental researches showed, a carrying capacity of natural ecosystems is seriously and irreversibly exceeded. Peak oscillations of everyday and year average temperature, tornados, floods, forest fires as well as well observable dangerous environmental pollution are the only perceivable signs of the global ecosystem instability. Therefore, a changing global man-nature metabolism is a new front for humankind which is potentially capable to undermine the basic rule of games of any social order. It is especially urgent when world institutional system is in transition. In essence, the sociology of critical areas and states is the sociology of action. As S. Yuan insisted, 'In facing the problem of the production of society, sociologists must strive for a transition from a sociology of structure to a sociology of action' (Yuan, 2008: 399).

Although an Islamic terrorist threat in Russia is beyond the frame of this article, one quotation should be made. 'The return of even a limited number of jihadists from Iraq or Syria can pose a security challenge to Russia. If they go to the North Caucasus, they would likely serve as just one complicating or destabilizing factor in the region. If they were to go elsewhere in Russia, even a few returnees could help fill a critical gap among radicalizing cells with among radicalizing cells with more universal agendas between the intent to carry out acts of violence or terrorism and capacity to do so. This could spur Islamist terrorist attacks of a new type that are not necessarily related to the North Caucasus. No less worrisome is the broader ideological influence of IS (Islamic State): not only its military successes and propaganda but it efforts to build a "physical" territorially-based caliphate for the here and now can have an impact, even it is one that only appeals to very few Russia's Muslimus' (Stepanova, 2015a). Again, it is clear that network and spatial structure of terrorism might be tightly binds together.

\section{Education, science, media, grassroots}

Recently, these institutes of modern society are separated. An activity of schools and universities are subject-oriented and very seldom aimed at practical problem-solving. But everyday life and carrier of students, postgraduates and sophisticated researches depends on how quick and efficient they would solve particular public, professional and private problems. Young humanitarians and sociologists in particular are oriented either on making carrier in a particular research field or on becoming the public figures and politicians. My own experience showed that my post-graduates are more concerned themselves with the search of a profitable place of work than with studies aimed at resolving acute modern social issues. In general, by and large the resolving of acute social problems as such has become a by-product of endless chain of grants. But these grants support the short-term field research, which do not allow implement a longitude for resolving, for example, such huge problem as the economic and cultural roots of current terrorists' wave. More than that, I observe that in comparison with the Soviet times my post-graduates intend to escape to study and even to discuss the actual problems of their country's development. They more inclined to a routine job as making synopsis, questionnaire compiling and other forms of desk-work. It is indicative that in the run of terrorists' attacks in the EU no one of my postgraduates tried to discuss these tragic events with me. 
To my mind, modern media and especially television are usually dispersing a human attention, converting it into 'kaleidoscope' of messages and opinions. Media continue to translate dialogues between experts on current tragic events whereas they should constantly teach lay people how to minimize sudden threats and risks. As Paris and Brussels cases showed, when media translated the statements of officials and influential experts, ordinary citizens turned to their cellphones and social networks. It is rather indicative that the response of social networks (twitter, etc.) has been nearly immediate. In our risky age the schools, sciences and media should not only to inform people but teach them how to behave in particular critical cases; and at the same time, not to be subjected to panic and fear. The joint activity of the above four institutions activity should be concentrated on defense, medical aid and psychological help.

To prevent any terrorist attack is impossible. Though, well-trained grassroots and even separate individuals are capable to minimize its consequences. I think that toe content of a notion 'grassroots' should be reconsidered. Day by day, rank-andfile people are training everywhere: at homes, offices, special summer schools as well as by the vet complicated urban life as such. Therefore, basing on the F. Fisher's (2003) idea of an 'expert-citizen' as a valuable social actor, the sociologists must make one step forward for recognizing the double nature of modern citizen. That is why l've introduced the notions of professional-citizen and professional-civic organizations (Yanitsky, 2014). This idea well corresponds with M. Byrawoy's understanding of public sociology (Burawoy, 2008).

It seems to me that we all forgot such notion as civic defense. A state is incapable to disperse its security and military troops to defense each office and apartment house. A danger to convert critical state into police state exists. Nevertheless, urban citizens should be prepared to a terrorist attack. It means in particular, the urban dwellers should decisively turn form socializing into the role of consumers towards the role of professional citizen. The case of the civic defense under conditions of warfare is a separate issue. But as one can see in many regions and locals of the world the difference between critical state and war is rather conditional. Especially as we speak about various forms of 'hybrid wars' (Yanitsky, 2015).

\section{Social and psychological characteristics}

As Arie Kruglanski wrote in his blog (Reuters.com), 'A puzzling feature of recent Paris massacres is that families and friends of the perpetrators professed no linking that anything unusual is afoot; no indication that their intimates were embarking on a vicious mayhem of innocents where they themselves will likely die.' In particular, it seems that Parisians never seem to know about the killers or bombers in their apartment houses. At the same time, the typical reaction of terrorists' neighbors: 'If she or he could do it means that anybody of my neighbors could do it.'

The peaceful neighbors' typical reaction - 'we couldn't even imagine something like that' - is well explained. On the one hand, such reaction was a form of psychological defense. On the other hand, it was a mean to relieve themselves of any responsibility on tragic events. This reaction resembles ne Russian proverb: 'That is nothing to do with me.' Even the close to terrorists' relatives tried to relieve from such a responsibility. The typical answer to reporter question: 'I never supposed that such behavior could be possible in our family.' Or another variant: 'I didn't see any preparations for it,' 'It is un believable', etc.

But more deep insight showed another picture. As one expert put it, the terrorists' families may 'refuse to accept the alienation and strangeness' of their radicalized kids. As it has been revealed a bit later, the terrorists' families and friends were aware of their fixed purposes. Nevertheless, the families tried to behave as nothing happened. It means that they knew more that they told to journalists. As Kruglanski concluded, 'The challenge, therefore, is to work with social networks of youth at risk of radicalization, increase their vigilance and facilitate their readiness to "say something" when "seen something."'

At that time the two extremes had appeared: on the one side peaceful and slack inhabitants and purposeful and armed combatants on the other. On the one side those who maintain their primary eco-structure (Yanitsky, 2012), implement their individual life plans and subjected to the routine of everyday urban life, whereas on the other those who armed with terrorist ideology and prepared to kill and to be killed. To my mind, terrorists are the 'Other people' in the utmost sense of the word. Such persons are not only alienated socially and psychologically, but they never more identify themselves with social milieu in which the live. Psychologically, these people are on the brink of this world. At the same time, they perceive the surrounding world in black and white.

There are some interesting findings which, to my mind, have a more general significance. First, 'There was no uniform profile of lone-actor terrorists.' Second, 'In the time leading up to most lone-actor terrorist events, evidence suggests that other people generally knew more about the offender's grievance, extremist ideology, views and/or intend to engage in violence.' Third, 'A wide range of activities and experiences preceded lone-actors' plots of events.' Four, 'Many but not all lone-actor terrorists were socially isolated. Five, 'Lone-actor terrorists regularly engages in detectable and observable range of activities with a wider pressure group, social movement or terrorist organization.' Six, 'Lone-actor terrorist events were rarely sudden and impulsive.' And further, 'Typically lone-actor terrorist events emerge from a gradual chain of behaviors. This chain includes the steps of adopting an extremist ideology, thinking about engaging in violence, acquiring the necessary materials and/or training and finally committing the offense groups.' Seven, 'Despite the diversity of loneactors terrorists, there were distinguishable differences between subgroups,' for example, between right-wing and singleissue offenders (Gill et al., 2013).

Finally, some words of a more general problems. Russian orientalists draw attention foe the processes of eroding of national identity and cultural nucleus which are peculiar to the modern phase of globalization and modernization. Russian orientalists underline the necessity to protect and maintain the cultural nuclei despite of the growing interdependence of 
the world (Mirskiy, 2009, 2014). I see these nuclei as a kind of medicine against the spread of terrorism because radical and terrorist cells could be considered as a new weapon of modern - network - war. As Russian researcher E. Stepanova noted, 'In certain ways, some of...radicalized cells and individuals appear to more closely resemble self-generating jihadi cells in Europe than the North Caucasus underground (even if they are still much fewer than homegrown European jihadi cells). Remarkably, this type of cells, nit mired in the North Caucasus' contextual dynamics, is in fact more likely to develop an interest in the ideology and agenda of the "global" versions of Islamist jihadism. They also appear to have a better grasp of transnational jihadi propaganda, increasingly spread though modern information and communication channels and involving more markedly transnationally-minded popularizers and preachers. In Russia, this trend was set by a native Siberian concert to Islam, Said Buryatski (killed in 2010) who made a point of reaching out to new audiences, such as educated urban youth across the country' (Stepanova, 2015).

\section{Conclusions}

First, there is a qualitative difference between critical areas and state of emergency. Critically areas are usually spatially fixed, whereas a state of emergency is a much more indifferent in its scale and consequences. In modern world the majority of orders and structures are man-made, socially constructed and politically governed. Second, the major features of extremely critical, i.e. terrorists', type of human ecosystems are the following: unseen, maximum closed, networkstructured, armed and aimed at the distraction of the existing social order. As one resident said, 'At this point, I never thought he was a suicide bomber, he was a customer like everyone else.' In more general terms, all things and processes around us are potentially double-purposed. Therefore, aims, goals, strategies and tactics come to the forefront in the struggle against terrorism. Third, any state of emergency is a kind of all-embracing and all-penetrating risk in its utmost form. It cannot be conquered by one mighty strike of a state power. The struggle against terrorism is a multisided and long-term process. It is now clear that these kinds of all-embracing risks are not only of structural character. Social chaos, poverty and injustice somewhere 'there' generate 'feedback' first of all in the form of radical and extremist ideologies. And these ideologies have the backers and sympathizers 'here' and across the world.

Four, terrorism cannot be eliminated by police, military or special forces only. It is an urgent task for civil society mobilization as well. Therefore, schools, sciences and media should not only to inform people but teach them how to behave in critical cases. Five, since the terrorism is organized as an ideologically targeted and network-organized social system this phenomenon can be represented and studied as a specific human ecosystem, though it will be more correct to name it as non-human. These overt ecosystems is rather difficult to detect because they can be in a 'sleeping' regime for a long time. It is not the beginning of the World War III but the mass terrorism is one step more toward it. Six, any critical system seriously changes an existed man-nature social metabolism. Seven, any critical system (especially if it is terrorist one) seriously changes an existed man-nature social metabolism. These shifts are risky because they cannot be indicated and prevented at once. Natural disasters and man-made accidents are sudden and not in time detectable events like sharp oscillations of magnetic field or temperature fluctuations and even global warming. It means that all these nature and man-made anomalies means that the study of an extreme way of life as important as normal one. Eight, in the global risk society all social institutes should be prepared to respond to the emerging risks locally, i.e. here and now. Besides, terrorism as a social phenomenon is a high-level risk but urges state and civil society to work hand in hand. Ten, today any social order not a steady state but the process. Therefore, the socio-ecological metabolism is an indicator of stability of any social order. The current risks produced by changing global man-nature relations as well as by social metabolism as such are the new front for humankind which is capable to undermine the basic rule of games of any social order. The emergence of critical states is one more argument for the shifting a sociological focus from structure to action. Anyhow, a production of society by action is still remains an acute issue.

Funding: the paper is one of the results of the project 'Complex research and compiling interdisciplinary model of socioecological metabolism of modern Russian city', grant No 15-06-00158, supported by Russian fond of basic research.

\section{REFERENCES}

[1] Beck U. 1992. Risk Society. Toward a New Modernity. London: SAGE.

[2] Beck U. 1999. World Risk Society. Malden, MA: Polity Press.

[3] Beck U. 2015. Emancipatory Catastrophism: What does it mean to Climate Change and Risk Society. Current Sociology, 63 (1): 75-88.

[4] Boyden S., S. Millar, K. Newcombe and B. O'Neill. 1981. The Ecology of a City and its People. The Case of Hong Kong. Canberra: Australian National University Press.

[5] Burawoy M. 2008. What is to be Done? Theses on the Degradation of Social Existence in a Globalizing World. Current Sociology 56 (3): 351-59.

[6] Ermolaeva P. 2015. Sotsial'no-Ecologicheskyi Metabolizm Gorodov: Konsrptualizatdyia, Nauchnye Shkoly, Sovremennye Zarubezhnye Issledovaniya [Socio-ecological Metabolism of Cities: Concepts, Scientific Schools, Recent Research]. Sotsiologicheskaya nauka i sotsial'naya praktika, 3 (11): 34-50.

[7] Fisher F. 2003. Citizens, Experts, and the Environment. The Politics of Local Knowledge. Durham and London: Duke University Press. 
[8] Fisher-Kowalski M. 1997. Society's Metabolism: On the Childhood and Adolescence of a Rising Conceptual Star, in Redklift M. and G. Woodgate, eds. The International Handbook of Environmental Sociology. Northampton, MA: Edward Elgar. Pp.119-137.

[9] Fisher-Kowalski M. and H. Haberl. 2007. Socioecological Transitions and Global Change. Trajectories of Social Metabolism and Land Use. Vienna: Klagenfurt University.

[10] Kennedy C., Cuddihy J., Engel Yan J. 2007. The Changing Metabolism of Cities. Journal of Industrial Ecology. (11): 43-59.

[11] Mirskiy G. 2009. Identichnost' - Kluchevoe Slovo [The Identity is a Key Word]. Bezopasnost' Evrazii, No 4: 525-530.

[12] Mirskiy G. 2014. The West is playing in to Moscow's Hands in Syria. Financial Times (in print).

[13] Newcombe K., Kalma J., Aston A. 1978. The Metabolism of a City: The Case of Hong Kong. Ambio, 7: 3-15.

[14] Smith D. 2008. Globalization, Degradation and the Dynamics of Humiliation. Current sociology, 56 (3): $371-379$.

[15] Stepanova E. 2015. North Caucasus - A Wall Against or a Bridge for IS? International Security Analysis. Available at: http://russiancouncil.ru/en/inner/?id 4=6269\&active id 11=66\#top-content

[16] Stepanova E. 2015a. The "Islamic State" as a Security Problem for Russia. The Nature and Scale of the Threat. PONARS Eurasia Policy Memo, No 393, October. Current sociology, 56 (3): 371-379. Available at:

[17] http://www.ponarseurasia.org/site/default/files/policy-memos-pdf/Pepm393 Stepanova Oct2015-0.pdf

[18] Wolman A. 1965. The Metabolism of Cities. Scientific American 213 (3): 179-190.

[19] Yan, Shen. 2008. Strong and weak intervention: Two Pathways for Sociological Intervention. Current sociology, 56 (3): 399-404.

[20] Yanitsky O. 2012. A Primary Eco-Structure: The Concept and its Testing. Social Analysis, 2 (2): 7-24.

[21] Yanitsky O. 2012a. The 2010 Wildfires in Russia. An Ecosociological Analysis. Sociological Research, 51 (2): 57-75.

[22] Yanitsky O. 2013. Metabolicheskaya kontseptsiya sovremennogo goroda [Metabolic concept of a modern city]. Sotsiologicheskaya nauka i sotsial'naya praktika, 3: 16-32.

[23] Yanitsky O. 2014. Sociology of Critical Areas. Open Journal of Social Science Research. 2 (3): 112-118. Available at: http://manuscript.sciknow.org/uploads/ojssr/pub/ojssr 140963345.pdf

[24] Yanitsky Oleg. 2015. Are the Sociologists Well Prepared to the Modern War? Journal of Social Sciences Research, 6 (3): 1990-1998.

[25] Available at: http://cirworld.com/journals/index.php/jssr/article/view/3680/pdf_99

[26] Yanitsky O. 2015. Professional'nye grazhdanskie organizatsii: opyt integrativnoi interpretatsii. [Professional-civic organizations. The experience of integrative interpretation]. Sotsiologicheskaya nauka i sotsial'naya praktika 2(10); 70-87.

[27] Gill P., Horgan J. and Deckert P. 2013. Bombing Alone: Tracing the Motivations and Antecedent Behaviors of Lone-Actor Terrorists. Journal of Forensic Sciences (on-line). Vol. 59 (2): 425-435.DOI: 10.1111/1556-4029.12312

\section{Author' biography with Photo}

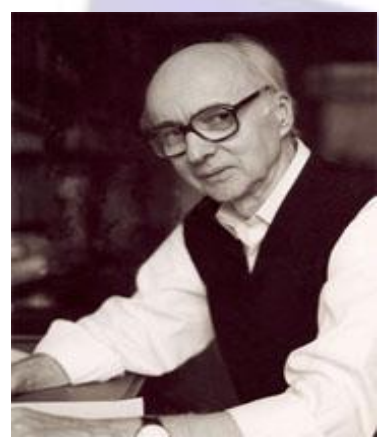

\section{Biographical Note}

Yanitsky Oleg Nikolaevich is a professor and the head of the department of socioecological research at the Institute of sociology of Russian academy of sciences. His research topics are environmental politics and social movements, environmental and man-made catastrophes, risk and biographical research. He wrote 15 books (four in English) and about 300 articles in Russian and English. From 1982 onwards, he published the articles in the International social science journal, International sociology, the International Sociology review of books, Current sociology, Innovation and in some others. He was the participant of the UNESCO's 'Man and the Biosphere' program (1976-91), and 'The World social science report' in 2012-13. Avocations: oil painting, collecting oral life histories. 